Asian-Australasian Journal of Food Safety and Security

ISSN 2523-1073 (Print) 2523-2983 (Online)

www.ebupress.com/journal/aajfss

\title{
Article \\ Detection of the amount of residue degradation rate of six commonly used insecticides in cauliflower under supervised field trial
}

\author{
Md. Sultan Ahmed ${ }^{1}$, Md. Mohsin Ali Sardar ${ }^{2}$, Masum Ahmad ${ }^{2}$ and Kamal Humayun Kabir ${ }^{1}$ \\ ${ }^{1}$ Entomology Division, Bangladesh Agricultural Research Institute (BARI), Joydebpur, Gzipur, Bangladesh \\ ${ }^{2}$ Department of Entomology, Bangladesh Agricultural University, Mymensingh, Bangladesh
}

${ }^{*}$ Corresponding author: Md. Sultan Ahmed, Division of Entomology, Bangladesh Agricultural Research Institute, Joydebpur, Gazipur-1701, Bangladesh. E-mail: sultan_palbari@yahoo.com

Received: 07 November 2018/Accepted: 27 November 2018/ Published: 29 November 2018

\begin{abstract}
The present study was made to detect the amount of residue degradation rate of insecticides in cauliflower under supervised field trial. Six field trials were carried out sprayed with recommended dose of acephate $(2 \mathrm{~g} / \mathrm{L}$ of water), cypermethrin $(1 \mathrm{ml} / \mathrm{L}$ of water) and diazinon, malathion, quinalphos and fenitrothion ( $2 \mathrm{ml} / \mathrm{L}$ of water of each), respectively. Samples were collected at $0,1,3,5,7,10$ and 15 days after spray (DAS). The degradation rate of cypermethrin, diazinon, quinalphos and fenitrothion were detected up to 10 days after spray (DAS) in cauliflower, while malathion and acephate could be detected at 5 and 15 DAS respectively. The detected quantities were above Maximum Residue Limit (MRL) up to 7 DAS for quinalphos, Fenitrothion and acephate, 5 DAS for diazinon and cypermethrin and 3 DAS for malathion. Malathion degraded quickly and acephate degraded slowly as compared to other tested insecticides. Therefore, malathion might be use for cauliflower cultivation having waiting period of 5 DAS and incase of diazinon and cypermethrin it was 7 DAS. Quinalphos, fenitrothion and acehate had higher waiting period of 10 DAS which might be due to slower rate of degradation.
\end{abstract}

Keywords: degradation; insecticide; residue; DAS; MRL; cauliflower

\section{Introduction}

The present production technology of vegetables has been greatly changing due to the demand of large quantity of vegetables in Bangladesh both for commercial and domestic purposes. The vegetable growers mostly adopt control measures with the application of chemical insecticides. The cauliflower is major vegetable and also grown commercially in Bangladesh. The farmers and commercial growers apply huge quantity of insecticides in the cultivation of cauliflower that inflicts several problems among which documentation of left over residues of insecticides on edible vegetables has become most prominent and urgent need for consumers. The use of insecticides viz., synthetic pyrethroid and organophosphorus are the major means for the control of insect pests of vegetables in the field than other management options. The chemical means are vital and provide a rapid, cost-competitive and typically effective pest management tool (MacIntyre et al., 1989). As there is no other suitable alternative method of controlling the insect pests, the growers solely depend on insecticides when pests attack the plants. It was understood from farmers' interview that they use insecticides irrationally and indiscriminately (Kabir, 1996; Anon, 2001; Ahmed et al., 2005). A considerable number of farmers sell vegetables immediate after spray or at an interval of 0-2 days after spray (Anon, 2000). This led to assume that over-sprayed vegetable consumers might face health hazards and environment might be over loaded with insecticide residue. Due to lack of education, the farmers of Bangladesh do not follow the prescribed dosages and use insecticides at any stage of the crop without any awareness of the residues and their adverse effects on human health. Documentation of left over residue in the crop and environment are inevitable to make the awareness among the end users, consumers and policy planners. The detection and monitoring of pesticide 
residue particularly in vegetable and fruits is being done in regular basis in many countries (Krol et al., 2000; Van der Schee, 2002; Kumar et al., 2004; Rajeswaran et al., 2004). Extensive deliberate use of pesticides has resulted in contamination of our vital supplies, air, water and food. Pesticide being toxic can become a potential hazard to the manufacturers, the user, the public at large and the environment (Antle and Pingali, 1994). The risk to humans may be short term as well as long term depending on the persistence of the insecticide and the exposure period. At present, the detection, identification and quantification of pesticide in the food becoming the public interest. But very little references are available on the presence of pesticides in vegetables in Bangladesh (Khatoon et al., 2004). The present study was undertaken to detect the amount and degradation rate of residue of malathion, diazinon, fenitrothion, quinalphos, acephate and cypermethrin in cauliflower.

\section{Materials and methods}

Six insecticides malathion, diazinon, fenitrothion, quinalphos, acephate and cypermethrin were sprayed separately as foliar treatments by knapsack sprayer in six plots of cauliflower with prescribed dose rate and marketable size of samples were collected randomly from each plot of cauliflower in six different supervised field trials at $0,1,3,5,7,10$ and 15 days after spray (DAS) of diazinon, malathion, quinalphos, fenitrothion (2 $\mathrm{ml} / \mathrm{L}$ of water of each), acephate $(2 \mathrm{~g} / \mathrm{L}$ of water) and cypermethrin $(1 \mathrm{ml} / \mathrm{L}$ of water), respectively. Recommended cultural practices including irrigation and soil management were followed. The formulated products of those were Rison 60 EC, Malataf 57 EC, Biolux 25 EC, Sumithion 50 EC, Asataf 75 SP and Ripcord $10 \mathrm{EC}$, respectively. The purity of all the formulated insecticides were tested in the laboratory and found to be $100 \%$ pure. The standard for all the insecticides were obtained from Sigma-Aldrich Laborchemikalien, Gmbh P. O. Box-100262, D-30918, Seelze, Germany via Bangladesh Scientific Pvt. Ltd. Dhaka, Bangladesh. Standards of all the insecticides contained $99.6 \%$ purity.

\subsection{Extraction, separation and clean up of cauliflower samples}

Collected samples ( $\geq 250 \mathrm{~g}$ ) were chopped by knife and mixed well. A sub sample of $20 \mathrm{~g}$ was taken into a wide mouth jar then $100 \mathrm{ml}$ of hexane was added to it. Sodium Sulphate $\left(\mathrm{Na}_{2} \mathrm{SO}_{4}\right)$ was also added with sample until water was removed from the sample. The mixture was then macerated with high-speed homogenizer for 2 minutes. The homogenized material was then poured into $250 \mathrm{ml}$ conical flask and placed into the refrigerated shaker for $12 \mathrm{hrs}$ continuous shaking. After shaking, the slurry was filtered through whatman filter paper no.40 and a Buchner funnels with suction. The flask and filter cakes were rinsed with $25 \mathrm{ml}$ of hexane each. The filtrate was then transferred into $250 \mathrm{ml}$ round bottom flask and was dried to around 5-7 $\mathrm{ml}$ by evaporation using a rotary vacuum evaporator. Then, the concentrate filtrate was collected in a centrifuge tube adjusted at $10 \mathrm{ml}$ volume which was then centrifuged at $16500 \mathrm{rpm}$ for 10 minutes with laboratory refrigerated centrifuges. After centrifuge, supernatant was collected and cleaned up by Super Phase Extraction (SPE) cartridge. Then the final volume was kept in $10 \mathrm{ml}$ volumetric flask. Before injection, this volume was again cleaned up by High Performance Liquid Chromatography (HPLC) filter which was ready for injection in GC.

\subsection{Detection and quantification of insecticide residue in cauliflower samples}

The concentrated extracts were subjected to analysis by GC-2010 (Shimadzu). Flame Thirmionic Detector (FTD) was used for the detection of organophosphorus (e.g., quinalphos, diazinon, malathion, fenitrothion \& acephate) and Electron Capture Detector (ECD) for cypermethrin. The capillary column used in FTD was ATTM-1, $30 \mathrm{~m}$ in length, $0.25 \mathrm{~mm}$ inner diameter (ID) and $0.25 \mu \mathrm{m}$ film thickness and in case of ECD it was Optima-1 and length, ID and film thickness were the same. Nitrogen was used as carrier and make up gas in ECD and in FTD it was Helium. For GC-FTD, injection port temperature was $250{ }^{\circ} \mathrm{C}$, column oven initial temperature was $150{ }^{\circ} \mathrm{C}$ which went up to $220^{\circ} \mathrm{C}$ following $10 \mathrm{~min}$ incrimental time. Detector temperature 280 ${ }^{\circ} \mathrm{C}$, stop time $10 \mathrm{~min}$, current $1.0 \mathrm{pA}$, makeup flow $30 \mathrm{~mL} / \mathrm{min}$, hydrogen flow $1.5 \mathrm{~mL} / \mathrm{min}$ and air flow 145 $\mathrm{mL} / \mathrm{min}$ were also used for GC-FTD and in case of GC-ECD injection port température was $280{ }^{\circ} \mathrm{C}$, column oven initial temperature was $160{ }^{\circ} \mathrm{C}$ which went up to $270{ }^{\circ} \mathrm{C}$ following $10 \mathrm{~min}$ incremental time. Detector temperature was $300^{\circ} \mathrm{C}$. Stop time was 18 min, current and makeup flow was similar as GC-FTD.

Previous to the injection of the sample extract, standard solutions of different concentrations of five insecticides were prepared and injected with the above instrument parameters. The samples were calibrated (retention time, peak area, etc.) against four pointed calibration curve of standard solution of concerned insecticide. Each peak was characterized by its retention time. Sample results were expressed in $\mathrm{mg} / \mathrm{kg}$ automatically by the GC software which represented the concentration of the final volume injected. From this value the actual amount of insecticide residue present in the sample was determined by using the following formula. 
Residue in sample $(\mathrm{mg} / \mathrm{kg})$

Conc. obtained in injected volume $(\mathrm{mg} / \mathrm{kg}) \times$ Quantity of final volume $(\mathrm{L})$

Amount of sample taken $(\mathrm{kg})$

\section{Results}

The results of the analysis of diazinon, malathion, fenitrothion, quinalphos and acephate residue in cauliflower were analyzed using the GC-FTD and for cypermethrin GC-ECD was used. The results obtained from this analysis have been summarized in Table 1-6.

Table 1. Quantity of residue of diazinon (Rison 60 EC) estimated from cauliflower.

\begin{tabular}{llllll}
\hline $\begin{array}{l}\text { Days after } \\
\text { spraying }\end{array}$ & $\begin{array}{l}\text { Sample } \\
\text { weight }(\mathbf{g})\end{array}$ & $\begin{array}{l}\text { Total volume } \\
\text { prepared }(\mathbf{m l})\end{array}$ & $\begin{array}{l}\text { Injected volume } \\
(\boldsymbol{\mu l})\end{array}$ & $\begin{array}{l}\text { Concentration } \\
\text { obtained in final } \\
\text { volume }(\mathbf{m g} / \mathbf{k g})\end{array}$ & $\begin{array}{l}\text { Amount of residue } \\
\mathbf{l e f t}(\mathbf{m g} / \mathbf{k g})\end{array}$ \\
\hline 0 & 20 & 10 & 2 & 27.266 & 13.633 \\
1 & 20 & 10 & 2 & 9.002 & 4.501 \\
3 & 20 & 10 & 2 & 6.644 & 3.322 \\
5 & 20 & 10 & 2 & 2.460 & 1.230 \\
7 & 20 & 10 & 2 & 0.900 & 0.450 \\
10 & 20 & 10 & 2 & 0.050 & 0.025 \\
15 & 20 & 10 & ND & ND \\
\hline
\end{tabular}

Maximum Residue Limit of diazinon in cauliflower: $0.5 \mathrm{mg} / \mathrm{kg}, \mathrm{ND}=$ Not detected

Residue of diazinon was detected up to 10 DAS and the quantities were above Maximum Residue Limit (MRL) up to 7 DAS and these were $13.633 \mathrm{mg} / \mathrm{kg}, 4.501 \mathrm{mg} / \mathrm{kg}, 3.322 \mathrm{mg} / \mathrm{kg}, 1.230 \mathrm{mg} / \mathrm{kg}$ and $0.45 \mathrm{mg} / \mathrm{kg}$ at $0,1,3,5$ and 7 DAS, respectively. Sample of 10 DAS contained $0.025 \mathrm{mg} / \mathrm{kg}$ diazinon residue which is below MRL set by FAO-WHO (1993). No residue was detected at 15 DAS. These results more or less agree with the observation of Geigy (1956-67). He observed the diazinon residue level after spraying the field dose were $<0.1$ $\mathrm{mg} / \mathrm{kg}$ in cabbage at $7 \mathrm{DAS}, 0.4 \mathrm{mg} / \mathrm{kg}$ in cauliflower at $5 \mathrm{DAS}$ and $<0.1 \mathrm{mg} / \mathrm{kg}$ in cucumber at 7 DAS. Adnan et al. (2006) found diazinon residue above MRL up to 8 DAS in sweet pepper grown in green house.

Table 2. Quantity of residue of malathion (Malataf 57 EC) estimated from cauliflower.

\begin{tabular}{llllll}
\hline $\begin{array}{l}\text { Days after } \\
\text { spraying }\end{array}$ & $\begin{array}{l}\text { Sample } \\
\text { weight }(\mathbf{g})\end{array}$ & $\begin{array}{l}\text { Total volume } \\
\text { prepared }(\mathbf{m l})\end{array}$ & $\begin{array}{l}\text { Injected volume } \\
(\boldsymbol{\mu l})\end{array}$ & $\begin{array}{l}\text { Concentration } \\
\text { obtained in final } \\
\text { volume }(\mathbf{m g} / \mathbf{k g})\end{array}$ & $\begin{array}{l}\text { Amount of residue left } \\
(\mathbf{m g} / \mathbf{k g})\end{array}$ \\
\hline 0 & 20 & 10 & 2 & 12.368 & 6.184 \\
1 & 20 & 10 & 2 & 5.532 & 2.766 \\
3 & 20 & 10 & 2 & 1.062 & 0.531 \\
5 & 20 & 10 & 2 & 0.552 & 0.276 \\
7 & 20 & 10 & 2 & ND & ND \\
\hline
\end{tabular}

Maximum Residue Limit of malathion in cauliflower: $0.5 \mathrm{mg} / \mathrm{kg}, \mathrm{ND}=$ Not detected

The left over residue of malathion in the cauliflower sample had been detected up to 7 DAS, of which up to 3 DAS the quantity of residue were above MRL. At the 0 DAS the residue was $6.184 \mathrm{mg} / \mathrm{kg}$ and they were 2.766 $\mathrm{mg} / \mathrm{kg}$ and $0.531 \mathrm{mg} / \mathrm{kg}$ at 1 and $3 \mathrm{DAS}$, respectively. All these quantities were above MRL. The quantity decreased down to $0.276 \mathrm{mg} / \mathrm{kg}$ at 5 DAS which was below MRL. No residue was detected at 7 DAS. 
Table 3. Quantity of residue of quinalphos (Biolux 25 EC) estimated from cauliflower.

\begin{tabular}{llllll}
\hline $\begin{array}{l}\text { Days after } \\
\text { spraying }\end{array}$ & $\begin{array}{l}\text { Sample } \\
\text { weight }(\mathbf{g})\end{array}$ & $\begin{array}{l}\text { Total volume } \\
\text { prepared }(\mathbf{m l})\end{array}$ & $\begin{array}{l}\text { Injected volume } \\
(\boldsymbol{\mu l})\end{array}$ & $\begin{array}{l}\text { Concentration } \\
\text { obtained in final } \\
\text { volume }(\mathbf{m g} / \mathbf{k g})\end{array}$ & $\begin{array}{l}\text { Amount of residue } \\
\mathbf{l e f t}(\mathbf{m g} / \mathbf{k g})\end{array}$ \\
\hline 0 & 20 & 10 & 2 & 31.778 & 15.889 \\
1 & 20 & 10 & 2 & 22.084 & 11.042 \\
3 & 20 & 10 & 2 & 6.530 & 3.265 \\
5 & 20 & 10 & 2 & 1.842 & 0.921 \\
7 & 20 & 10 & 2 & 0.752 & 0.376 \\
10 & 20 & 2 & 0.196 & 0.098 \\
15 & 20 & 10 & ND & ND \\
\hline
\end{tabular}

Maximum Residue Limit of quinalphos in cauliflower: $0.2 \mathrm{mg} / \mathrm{kg}, \mathrm{ND}=$ Not detected

Residue of quinalphos was detected up to 10 DAS and the quantities were above MRL up to 7 DAS and these were $15.889 \mathrm{mg} / \mathrm{kg}, 11.042 \mathrm{mg} / \mathrm{kg}, 3.265 \mathrm{mg} / \mathrm{kg}, 0.921 \mathrm{mg} / \mathrm{kg}$ and $0.376 \mathrm{mg} / \mathrm{kg}$ at $0,1,3,5$ and 7 DAS, respectively. This insecticide remained $0.098 \mathrm{mg} / \mathrm{kg}$ residue which was below MRL at 10 DAS in cauliflower. No residue was detected at 15 DAS.

Table 4. Quantity of residue of fenitrothion (Sumithion 50 EC) estimated from cauliflower.

\begin{tabular}{llllll}
\hline $\begin{array}{l}\text { Days after } \\
\text { spraying }\end{array}$ & $\begin{array}{l}\text { Sample } \\
\text { weight }(\mathbf{g})\end{array}$ & $\begin{array}{l}\text { Total volume } \\
\text { prepared }(\mathbf{m l})\end{array}$ & $\begin{array}{l}\text { Injected volume } \\
(\boldsymbol{\mu l})\end{array}$ & $\begin{array}{l}\text { Concentration } \\
\text { obtained in final } \\
\text { volume }(\mathbf{m g} / \mathbf{k g})\end{array}$ & $\begin{array}{l}\text { Amount of residue } \\
\mathbf{l e f t}(\mathbf{m g} / \mathbf{k g})\end{array}$ \\
\hline 0 & & & 2 & 31.560 & 15.780 \\
1 & 20 & 10 & 2 & 20.238 & 10.119 \\
3 & 20 & 10 & 2 & 9.054 & 4.527 \\
5 & 20 & 10 & 2 & 2.606 & 1.303 \\
7 & 20 & 10 & 2 & 0.786 & 0.393 \\
10 & 20 & 10 & 2 & ND & ND \\
\hline
\end{tabular}

Maximum Residue Limit of fenitrothion in cauliflower: $0.1 \mathrm{mg} / \mathrm{kg}, \mathrm{ND}=$ Not detected

Residue of fenitrothion was detected up to 7 DAS and all of the amounts were above Maximum Residue Limit. The detected quantities were $15.780 \mathrm{mg} / \mathrm{kg}, 10.119 \mathrm{mg} / \mathrm{kg}, 4.527 \mathrm{mg} / \mathrm{kg}, 1.303 \mathrm{mg} / \mathrm{kg}$ and $0.393 \mathrm{mg} / \mathrm{kg}$ at 0,1 , 3,5 and 7 DAS, respectively. No residue was detected at 10 DAS.

Table 5. Quantity of residue of cypermethrin (Ripcord 10 EC) estimated from cauliflower.

\begin{tabular}{llllll}
\hline $\begin{array}{l}\text { Days after } \\
\text { spraying }\end{array}$ & $\begin{array}{l}\text { Sample } \\
\text { weight }(\mathbf{g})\end{array}$ & $\begin{array}{l}\text { Total volume } \\
\text { prepared }(\mathbf{m l})\end{array}$ & $\begin{array}{l}\text { Injected volume } \\
(\boldsymbol{\mu l})\end{array}$ & $\begin{array}{l}\text { Concentration } \\
\text { obtained in final } \\
\text { volume }(\mathbf{m g} / \mathbf{k g})\end{array}$ & $\begin{array}{l}\text { Amount of residue left } \\
(\mathbf{m g} / \mathbf{k g})\end{array}$ \\
\hline 0 & 20 & 10 & 2 & 32.578 & 16.289 \\
1 & 20 & 10 & 2 & 22.064 & 11.032 \\
3 & 10 & 2 & 6.2 & 3.100 \\
5 & 20 & 10 & 2 & 2.728 & 1.364 \\
7 & 20 & 10 & 2 & 0.840 & 0.420 \\
10 & 20 & 10 & 2 & 0.438 & 0.219 \\
15 & 20 & 10 & ND & ND \\
\hline
\end{tabular}

Maximum Residue Limit of cypermethrin in cauliflower: $0.5 \mathrm{mg} / \mathrm{kg}, \mathrm{ND}=$ Not detected

The residue of cypermethrin in cauliflower sample had been detected up to 10 DAS, of which up to 5 DAS the quantity of residue were above MRL. At the 0 DAS the residue was $16.289 \mathrm{mg} / \mathrm{kg}$ and they were $11.032 \mathrm{mg} / \mathrm{kg}$, $3.100 \mathrm{mg} / \mathrm{kg}$ and $1.364 \mathrm{mg} / \mathrm{kg}$ at $1 \mathrm{DAS}, 3 \mathrm{DAS}$ and $5 \mathrm{DAS}$, respectively. All these quantities were above MRL. While samples of 7 and 10 DAS contained $0.420 \mathrm{mg} / \mathrm{kg}$ to $0.219 \mathrm{mg} / \mathrm{kg}$ residue which were below MRL set by FAO-WHO (1993). No residue was detected at 15 DAS. 
Table 6. Quantity of residue of acephate (Asataf $75 \mathrm{SP}$ ) estimated from cauliflower.

\begin{tabular}{llllll}
\hline $\begin{array}{l}\text { Days after } \\
\text { spraying }\end{array}$ & $\begin{array}{l}\text { Sample } \\
\text { weight }(\mathbf{g})\end{array}$ & $\begin{array}{l}\text { Total volume } \\
\text { prepared }(\mathbf{m l})\end{array}$ & $\begin{array}{l}\text { Injected volume } \\
(\boldsymbol{\mu l})\end{array}$ & $\begin{array}{l}\text { Concentration } \\
\text { obtained in final } \\
\text { volume }(\mathbf{m g} / \mathbf{k g})\end{array}$ & $\begin{array}{l}\text { Amount of residue } \\
\text { left }(\mathbf{m g} / \mathbf{k g})\end{array}$ \\
\hline 0 & & & 2 & 13.070 & 6.535 \\
1 & 20 & 10 & 2 & 9.704 & 4.852 \\
3 & 20 & 10 & 2 & 4.114 & 2.057 \\
5 & 20 & 10 & 2 & 3.206 & 1.603 \\
7 & 20 & 10 & 2 & 1.186 & 0.593 \\
10 & 20 & 10 & 2 & 0.324 & 0.162 \\
15 & 20 & 10 & 0.150 & 0.075 \\
\hline
\end{tabular}

Maximum Residue Limit of acephate in cauliflower: $0.5 \mathrm{mg} / \mathrm{kg}, \mathrm{ND}=$ Not detected

The results revealed that residue of acephate could be detected up to 15 DAS. The quantities of residue were above MRL up to 7 DAS and these were $6.535 \mathrm{mg} / \mathrm{kg}, 4.852 \mathrm{mg} / \mathrm{kg}, 2.057 \mathrm{mg} / \mathrm{kg}, 1.603 \mathrm{mg} / \mathrm{kg}$ and 0.593 $\mathrm{mg} / \mathrm{kg}$ at $0,1,3,5$ and 7 DAS, respectively. The quantity decreased down to $0.162 \mathrm{mg} / \mathrm{kg}$ at 10 DAS and 0.075 $\mathrm{mg} / \mathrm{kg}$ at 15 DAS which were below MRL set by FAO-WHO (2008). Acephate was detected for a longer period than any other tested insecticide and it was found up to 15 DAS in which MRL values $(0.5 \mathrm{mg} / \mathrm{kg})$ were above up to 7 DAS with $0.593 \mathrm{mg} / \mathrm{kg}$ in cauliflower.

\section{Discussion}

From the degradation stand point of view, out of six insecticides malathion disappeared quickly detected up to 5 DAS and the quantities were above MRL upto 3 DAS in cauliflower. Acephate degraded slowly and its residue was detected up to 15 DAS which was the longer degradation period than other tested insecticides and degraded 2 days later at above MRL. Diazinon, quinalphos and cypermethrin were detected up to 10 DAS showing above MRL at 5 DAS in diazinon and cypermethrin, but quinalphos degraded 2 days later at above MRL. Thus Fenitrothion detected up to 7 DAS which was 2 days longer than diazinon and cypermethrin at above MRL value. The plant behavior might be related to physico-chemical properties of pesticides, for example uptake by plants, metabolism, etc. (O' Brein, 1967; Virgina and Bajet, 1996). Tejada et al. (1983) showed that the disappearance of residue in and on plants is the effect of the interaction of environmental conditions such as the wind, rain, sun, humidity and temperature and chemical and physical factors such as volatilization and growth of the plant. Geigy (1956-67) observed the diazinon residue levels after spraying the field dose were $<0.10$ $\mathrm{mg} / \mathrm{kg}$ in cabbage at 7 DAS and $0.40 \mathrm{mg} / \mathrm{kg}$ in cauliflower at 5 DAS. Singh and Kalra (1992), Agnihotri et al. (1990) and Singh and Kalra (1996) found detectable level of residue of cypermethrin and fenvalerate up to 7 days of spraying of recommended dose. The results of the study are in corroborate with the results of mentioned authors although their method of analysis were different.

\section{Conclusions}

The degradation rates of qunalphos, fenitrothion, cypermethrin and diazinon were found slower in cauliflower, longer in acephate and faster in malathion. So, malathion might be use for cauliflower cultivation which would be harvested at shortest period of time having withholding period of 3 DAS. Diazinon and cypermethrin might also be included in cauliflower cultivation with pre harvest interval (PHI) of 7 DAS. Quinalphos, fenitrothion and acehate having longer period with PHI of 10 DAS which could not ensure the safety use of these insecticides in cauliflower.

\section{Conflict of interest}

None to declare.

\section{References}

Adnan I, Al-Samariee, AMS Khloud and AAB Mabrouk, 2006. Residue levels of three organophosphorus insecticides in sweet pepper grown in commercial green houses. Pesticide Sci., 22: 189- 194.

Ahmed MS, MA Sardar, MA Haque and KH Kabir, 2005. A survey on the pattern of insecticidal usage for the protection of brinjal (Solanum melongena) from the attack of insect pests in Jessore. Bangladesh J. Zool., 33: 57-63. 
Agnihotri NP, SN Sinha and AK Chakrabarti, 1990. Bioefficacy of some synthetic pyrethroid insecticides against Leucinodes orbonalis Guen. and their residues on brinjal fruit. Indian J. Ent., 52: 373-378.

Anonymous, 1993. Codex alimentarius, pesticide residues in food. Joint FAO/WHO Standards Program, FAO, Rome, Italy, Vol. 2, pp. 86-109.

Annonymous, 2000. Annual report 1999-2000, Entomology Division, Bangladesh Agricultural Research Institute, Joydebpur, Gazipur, Bangladesh

Anonymous, 2001. Coordinated research on insecticide residue and resistance in major vegetables grown in Bangladesh. Report on Contact Research Project, BARC, BARI, Joydebpur, Gazipur, 102 p.

Antle JM and PL Pingali, 1994. Pesticides, productivity and farmer health: A Philippine case study. American Journal of Agril. Economics, 76: 418-430.

Devi LS and C E Manjunath, 1985. Current Research, University of Agricultural Sciences, Bangalore, 14(4/6): 34-35.

Geigy Chemical Company, 1956-67. Unpublished data and methods of analysis in pesticide petitions, submitted to the U. S. Food and Drug Administration.

Kabir KH, ME Baksh, FMA Rouf, MA Karim and A Ahmed, 1996. Insecticide usage pattern on vegetable at farmer level of Jessore region in Bangladesh: a survey finding. Bangladesh J. Agril. Res., 20: 241-254.

Krol WJ, TL Arsenault, HM Pylypiu and MJ Mattina, 2000. Reduction of pesticide residues on produce by rinsing. J. Agric. Food Chem., 48: 46-70.

Kumari B, VK Madan, J Singh and TS Kathpal, 2004. Monitoring of pesticidal contamination of farm gate vegetables. J. Earth Environ. Sci., Springer Netherlands, 90: 65-71.

MacIntyre AN, N Allison and DR Penman, 1989. Pesticides: Issues and options for New Zealand. Ministry of the Environment, Wellington, New Zealand, 7: 29.

Van der Schee HA, 2002. Report of pesticide residue monitoring results of Netherlands. 2001. Inspectorate of Health Protection and Veterinary Public Health, Dee Haag, Amsterdam, Netherlands.

Rajeswaran J, I Merlin Kamal, S Chandrasekaran, R Jayakumar and S Kuttalam, 2004. Harvest time residue of carbosulfan in brinjal fruits. J. Food, Agriculture and Environment, 2: 276-277.

Khatoon JA, MS Islam, NM Talukder and M A Hossain, 2004. Monitoring the residue level of three selected pesticides in Red Amaranth. J. Biol. Sci., 4: 474- 479.

Kumar B, VK Madan, J Singh and TS Kathpal, 2004. Monitoring of pesticidal contamination of farm gate vegetables. J. Earth Environ. Sci., Springer Netherlands, 90: 65-71.

O’ Brien, RD 1967. Insecticides Action and Metabolism. AP New York, 332 p.

Singh IP and RL Kalra, 1992. Determination of residues of Cypermethin in brinjal fruits, leaves and soil. Indian J. Ent., 54: 207-216.

Singh IP and RL Kalra, 1996. Persistence and degradation of Fenvalerate on brinjal. Indian J. Ent., 58: 27-31.

Tejada AW, E D Magallona and EB Lakan-Ilaw, 1983. Insecticide residues in vegetables: Application of the modified approach to organophosphate insecticide residues in string bean (Vigna sesquipedalis Fruw.) Phil. Agr. U. P. Los Banos, 66: 405-416.

Virgina RO and C M Bajet, 1996. Pesticides in the Philippine environment. In: Proceedings. Anniversary and Annual Scientific Meeting, (Dizon, T D, Eusebio JE, Duenas JN, Palis FV and Mabbayad MO eds.). Pest Management Council of the Philippine, Davao City, pp. 61-77. 